\title{
Employee Loyalty And Its Impact On Firm Growth
}

Jasna Auer Antoncic, University of Primorska, Slovenia Bostjan Antoncic, University of Primorska, Slovenia

\begin{abstract}
Employees are crucial for the achievement of internal quality and consequently for business performance of companies. The quality of employees, their competencies, loyalty and commitment are extremely important for business performance achievement. For development of employee loyalty it can be important that employees find in work, which they perform, challenge, interest and the feeling of accomplishment. The way of treatment of employees in the organization is decisive in determining if employees will indeed become an integral part of the competitive advantage of the company. The paper focuses on employee loyalty and growth of companies. The hypothesis about the relationships between employee loyalty and firm growth was developed and empirically tested. Data collection was based of responses to the structured questionnaire on the sample of Slovenian companies from service and manufacturing industries. The hypothesis was tested by using regression analysis. Findings indicate a positive relationship between employee loyalty and firm growth, particularly for manufacturing firms. Recommendations for companies are also provided.
\end{abstract}

Keywords: employee loyalty; growth; manufacturing; services; regression analysis

\section{INTRODUCTION}

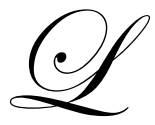

ong-term business objectives of the company can be achieved when employee loyalty can be established. In practice, it often happens that the employer expects or requires from its employees to be loyal, but fails to provide a positive atmosphere at work; such attempts to obtain loyalty can be almost always far from successful. The main objective of creating the environment of employee loyalty is to achieve a situation in which employees will knowingly and without coercion become committed, accept responsibilities and pursue them at their own best efforts. In order to achieve employee loyalty in the company, a company must take a good care of employees. A sense of belonging is associated with confidence and accepting the objectives and values of the firm and it is accompanied by the employees' willingness and commitment to the efforts (Mihalic 2008, 6-7). Employee loyalty can contribute to greater efficiency, better business results, firm growth, reduced employee turnover, etc. (Meyer and Allen 1997, 3; Antoncic and Hisrich 2004). Loyal employees also contribute to the creation of the image that the company has to its environment and outside stakeholders, such as customers (Meyer and Allen 1997, 3). The trust of employees in the company very importantly defines the employee welfare at work and satisfaction with work (Mayer 1991, 120). Internal service quality can influence employee satisfaction, employee loyalty and productivity (Heskett et al. 1994). Employees are key to achieving the internal quality of service in the company and hence for the business results of enterprises.

Business growth is an important element of business performance and is based on the performance of employees. Companies often emphasize the importance of economic performance and growth of the company, but often neglect their employees, who are an important element for sustainable development of the company (Antoncic 2002; Mozina 2002). Companies can come into trouble, when key employees start leaving the company because of mistrust and lack of confidence in the company, lack of acceptance of certain business decisions, and because of the neglect of their needs. In order to achieve the business objectives and the consequent growth of the company, the companies should strive to achieve employee loyalty (Mozina 2002). The focus of the paper is on employee loyalty and the relationship between employee loyalty and firm growth. In the following sections, the theory and the 
hypothesis are presented, methods are described, findings based on data from a sample of companies in manufacturing and service industries in Slovenia are presented, and conclusions are drawn.

\section{THEORY AND THE HYPOTHESIS}

Labor and business conditions are becoming increasingly tight in the today's business environments. Tensions, which have the nature of stress and crisis, are present in many enterprises. Intense competition requires from the company to operate and to adhere under the principle of excellence (Belbin 1993, 136). Companies, regardless of their size or activity, achieve their business results with employees (Merkac Skok 2008, 176). In order to achieve a positive atmosphere in the company, the active role of leadership is needed. It is necessary to focus on individuals, so that they can develop their capabilities (Driver et al. 1988). Managers should be aware of the importance of proper handling of employees; they should be oriented towards employees so that they respect their opinions, keep them well-informed in and act with tolerance to small errors in the work. There is no single way of leading and managing employees, which would be appropriate for any situation or any company, but adjustments to a given situation and time need to be made. If the company managers want that the work is successfully carried out, they must possess organizational and communication skills (Merkac Jump 2008, 182-183). The success of the company depends on internal and external public. If employees do not believe in the company leadership, then also the trust of the external public, such as buyers, journalists, can be reduced. Performance of key staff should be properly addressed and they should be given the possibility of faster acquisition of competencies (Joy-Matthews, Megginson and Surtees 2007, 236-243; Lobnikar 2006). Intellectual capital is an endless source of competitive advantage of firms (Tsui et al. 1997). The modern organization can have a complex structure and perform different functions; in the process of work it needs to coordinate and integrate many forms and knowledge, which can be related also to scientific methods and techniques. Central to this integration are human activities, thinking and behavior. Relationships between people are the basis underlying the modern management. A successful manager must cope with very complex environment, in which the knowledge about people is important and needs to be used in practice. In the corporate culture can be often found the causes of success or failure of a company (Fiedler 1993).

The loyalty of employees exists in the company, when employees believe in the objectives of the company, accept the objectives as their own, work for the common welfare, and want to stay in the company. Attachment to the company is developed in the circumstances of identification with the company. Employee loyalty can be a multifaceted construct, which is characterized by the identification of employees with the company's mission and with work ethic. The loyalty of an employee can be expressed through a feeling of the individual to belong to the company and the team of co-workers, whom he or she wants to help, and the willingness to support the company leader, to act in accordance with the work ethic and professionalism, to stay in the company in the time of crises, to have a will to do his or her work, to spread information about the good name of the organization, etc. (Varona 2002, 127). There are several kinds of loyalty, for example, the loyalty towards the team, work, managers, career, and organization. Organizational loyalty can be defined as the degree to which individuals feel being the part of the organization. Research shows (Mihalic 2008) that the right employee loyalty has been increasingly compromised lately, because of the increased mobility of employees, increased educational level and individual independence of people; people bond less and move more from one company to another than they did in the past. Reduced loyalty of employees is also evident elsewhere, for example in the mistrust in business decisions, in corporate environments experiencing poor internal information flow, management style, communication, etc. Such an attitude towards the company and work-environment does lead to the realization of a deeper meaning of work, which can be realized in a more permanent relationship, corroborated with a feeling of the presence of values and of trust in the common mission and vision (Mihalic 2008, 6-7). Sudden changes in companies also make it difficult to develop a sense of belonging among employees. A person, who has worked for the organization for a long period of his or her career, which is reaching towards the end, can also be loyal and still would not want to change the organization, recognizing the benefits he or she receives; therefore he or she remains in the organization and is loyal, although the origin of his or her loyalty is far from a general understanding of this concept (Meyer and Allen 1997, 3).

Loyalty is a feeling of positive orientation of employees related to the future direction and development of the company, which has an impact on current operations. It is a psychological bond, which binds individuals to the company and may involve multiple stages, for example, in the form of consent, identification or even internalization (Mesner Anolsek 1995, 34). In practice, it sometimes happens that an individual, who is satisfied with his or her 
work, will not belong to the organization or team, because of his or her characteristics and negative past experiences. The loyalty of employees is harder to achieve than their satisfaction with work. One major reason for this is that there can be a bilateral interest in achieving employee satisfaction, whereas the interest for employee loyalty is usually expressed or demanded unilaterally by the employer. But is the employer really trying to achieve loyalty of employees? Employee loyalty can be developed independently, mostly on the basis of job satisfaction. Therefore it is unreasonable to encourage employees directly to be loyal, as this may cause the opposite effect. In practice, it often happens that an employer requires from the employees to be loyal, but fails to ensure that the company would operate towards achieving employee satisfaction. Such attempts to obtain loyalty are usually unsuccessful, because employee loyalty cannot be developed without developing employee satisfaction. Employee satisfaction tends to affect employee loyalty and productivity (Heskett, 1994). Interpersonal trust in the organization (trust in managers and peers) can influence employee satisfaction and consequently employee loyalty (Matzler and Renzl 2006). Findings in modern organizational theory and practice lead to the realization of the fact that long-term objectives of the company can be achieved only when employee loyalty is developed (Mihalic 2008). The level of loyalty of employees to the company in general depends on the degree of acquisition of the objectives, strategy and results of the company by employees as their own objectives, strategy and results, which have a significant impact on their commitments and efforts. The creation of employee loyalty through the equation with the company can release huge human potential and direct it towards the achievement of business objectives. The main goal of the creation of employee loyalty through the equation process is achieved when employees are committed knowingly and without coercion. The basic conditions of high employee loyalty, such as familiarity with business objectives, ability to influence the setting and achievement of these objectives, and trust between superiors and subordinates, can only be achieved through the advanced employee participation in business decision making. A key purpose of managing employee loyalty is to develop, build and permanently maintain specific elements of human resource management (organizational climate, job stability, annual personal interviews, etc.), which in turn may facilitate and increase the level of employee loyalty (Mihalic 2008, 8-16). In-depth interviews with the boss can help employees clarify their role and their perception of what is expected from them. An employee can through such a conversation receive confirmation and compliance and may become more loyal (Majcen 2004,28). Relationships in the workplace can be very important in defining the wellbeing and commitment of employees at work. It has been shown (Mayer 1991, 120) that the physical wellbeing can be related to the mental wellbeing and that employees are willing to substitute well-paid jobs, when poor relationships exist in the company. Poor relationships between employees can also reduce the level of employee loyalty (Mozina 2002, 23-28). With open communication between different levels in the company (Antoncic 2008, 97-98) false information, misunderstanding, and wrong decision-making can be avoided (Welsby 2003, 56). The commitment of employees to the organization (Bush, Busy, and Hair Jr. 1990; Hartline and Ferrell 1996) can be considered an important element of employee loyalty and satisfaction (Auer and Antoncic 2009).

In order to improve internal collaboration in the company, managers must take into account the element of employee loyalty and other internal organizational elements, such as: organizational values, open communication and formal control; these elements may contribute to the innovation in the broadest sense, which can lead to growth of the company (Antoncic et al. 2002, 69; Mozina 2002, 23 Antoncic 2008, 97-98). As noted in the previous paragraphs, employee loyalty and conditions related to employee loyalty formation may affect growth of the company. Employee loyalty can have a positive impact on the efficiency of employees and is important for the development and growth of the company. Therefore, the relationship between employee loyalty and firm growth is expected to be positive. When examining the relationship between employee loyalty and firm growth, it needs to be noted that employee loyalty can be considered an integral part of employee satisfaction (Antoncic 2002, Auer and Antoncic 2009) and that a positive effect of employee satisfaction on firm growth was found in past research: indirectly through organizational support and values creation (Antoncic and Hisrich 2001, 2004; Antoncic and Zorn 2004; Antoncic 2007) and directly (Auer and Antoncic 2009). Employee loyalty can be linked to value growth (Duboff 1999). Employee loyalty can increase business performance, for example customer satisfaction (Heskett et al. 1994; Matzler and Renzl 2006), which can be important for firm growth. On the basis of the above discussion the following research hypothesis is postulated:

Hypothesis 1: Employee loyalty will be positively related to firm growth. 


\section{METHODS}

A survey questionnaire was used. A structured survey questionnaire was prepared in order to obtain unambiguous answers to specific questions. The questions were mainly closed, which allowed subsequent statistical analyses. Likert-type scale ratings of questions were mainly based on the scale ranging from 1-very untrue to 5-very true. Constructs were measured by questions that have been taken and adapted from previous research. Employee loyalty was measured by two questions from Mowday, Steers, and Porter (1979), Michaels at al. (1988). For the assessment of the dependent variable - firm growth - and control variables (industry, age and company size) questions from previous research were used (Antoncic 2002; Antoncic and Hisrich 2004; Antoncic 2007). The survey questionnaire included questions divided into three sections relating to employee loyalty, firm growth, and one section, which included the control variables (industry, age and size). The two main constructs showed good internal consistency. Employee loyalty included two items: employees feel very little loyalty to their organization (r) and employees talk up their organization to their friends as a great organization to work for (correlation coefficient 0.43 , sig. $=0.000$ ), whereas firm growth included three items measuring growth in terms of sales, employees and market share in the past three years (Cronbach alpha reliability was 0.75 , which indicates a satisfactory level of reliability).

Data collection was conducted via e-mail stating the purpose of the research. Questionnaires were sent to large, medium and small companies in Slovenia, which operated in service and manufacturing industries and had at least twenty employees. The questionnaires were addressed with the accompanying text to the key decision makers in the firm (CEOs). 134 usable questionnaires for analysis were returned. The majority of companies in the sample were between 11 and 20 years old. The majority of the companies had total annual sales of over 1.6 million to 4 million EUR. Most companies were small, having from 20 to 50 employees (full time equivalent).

Regression analysis was used to test the hypothesis. Composite variables for employee loyalty (independent variable) and firm growth (dependent variable) were calculated as means of construct items. Control variables firm age and size were included as additional independent variables in all regression equations. The impact of the industry control variable was checked so that the sample was divided into two parts, namely the manufacturing and service companies.

\section{RESULTS OF REGRESSION ANALYSIS}

The following are the results of regression analysis for testing the hypothesis and the impact of control variables: In examining Hypothesis 1, we found the association between employee loyalty and firm growth. The regression model was found significant $(\mathrm{F}=8.04$, sig. 0.000$)$. Corrected coefficient of determination is 0.13 , which means that $13 \%$ of the variance in the dependent variable can be explained by the independent variable. Standardized regression coefficient for the employee loyalty is 0.22 and is significant (sig. 0.006). Employee loyalty was therefore found positively related to growth of the company, which is consistent with the Hypothesis 1. Additional regression analyses were conducted for checking effects of control variables (age, size, industry). Firm age and size were added in the regression equation as independent variables. Results showed a negative association between age and growth (standardized coefficient -0.29 and significant: sig. 0.000), whereas no association was found between size and growth (standardized coefficient -0.01 , sig. 0.95). When checking the industry control variable the regression analysis was done separately for manufacturing and service firms. For manufacturing firms the relationship between employee loyalty and growth was positive and significant (standardized coefficient 0.17 , sig. 0.02), whereas this relationship was found positive but at a lower level of significance for service firms (standardized coefficient 0.14 , sig. 0.06). Overall, the hypothesis on the relationship between employee satisfaction and growth received moderate support. Employee loyalty can be important for firm growth, but this may hold more in manufacturing firms than in service firms. In addition, the results indicated that firm age can be negatively associated with firm growth.

\section{DISCUSSION AND CONCLUSION}

Employee loyalty can be important for growth of the company. The results of the regression analysis moderately confirmed the hypothesis. By using control variables (industry, age and size by number of employees), 
we came to additional conclusions. The control variable age of the firm showed a negative relationship with growth; the older the company the slower can be its growth, and vice versa. The company size was not found to affect its growth. The study results indicated that employee loyalty can be especially important for growth of manufacturing enterprises.

The role of employee loyalty is important in all businesses regardless of size and age. The main focus of this paper was on employee loyalty. The theoretical development of the role of employee loyalty and its relationship to firm growth was upgraded by using empirical quantitative analysis of the association between employee loyalty and firm growth. The regression analysis moderately confirmed the hypothesis. In addition, the influence of control variables was assessed. The key contribution of this study is the theoretical development and testing of the role of employee loyalty in firm growth. In addition to the scientific contribution, some recommendations for practice - for companies - can be given; recommendations can be important for firm growth: Employee loyalty can be important for firm growth. Employee loyalty can be particularly important for growth in manufacturing firms, whereas in the service sector it may be less important. Employee loyalty can be also important in terms of its relationship to overall satisfaction of employees, because employee loyalty cannot be directly affected by management, but more through building satisfaction elements (Auer and Antoncic 2009). Companies should ensure that their employees are adequately rewarded in the form of various bonuses, praise, the possibility of education, promotion, and the education for flexible behavior. The following elements can be more important than a good for many employees: interpersonal relationships, organizational climate, positive communication, and an adequate flow of internal information. By giving sufficient attention to these employee satisfaction elements, the level of employee loyalty in the company can increase, which can have a positive impact on firm growth. Managers should be aware of the importance of the role of employees for the development of the company. The way of managing employees can be crucial for the way employees talk about the company to their friends and to the organizational external environment. Companies should ensure that employees are proud to say to other people that they are part of the organization. The company can create a good image and reputation by taking a good care of its employees; this may also reduce the cost of promotion.

The study has also some limitations. The study was limited to employee loyalty as an important factor affecting the growth of the company. Other elements, which may be important for growth, were not included. The sample was limited to companies from Slovenia and not from other countries; the sample can be considered well representative of companies with twenty or more employees. The structured survey questionnaire was used, which limited but also assured exact answers to the questionnaire items. Answers about the company's growth were obtained through a questionnaire, which was answered by individuals, and not from the annual financial statements of companies. Collecting data on the growth and profitability of enterprises on the basis of perceptions of key decision makers in the company has proved to be adequate also in previous research (for example, Zahra 1991; Zahra 1993; Hisrich and Antoncic 2001; Antoncic and Hisrich 2004; Antoncic 2007). In future research other factors that are important for employees and firm growth can be included. Cross-cultural comparisons of findings may also improve the validity of the findings in future research. Despite the limitations, the study made an important contribution by examining employee loyalty and showing its impact on firm growth.

\section{AUTHOR INFORMATION}

Jasna Auer Antoncic is a researcher in the field of entrepreneurship at the Faculty of Management, University of Primorska, Koper, Slovenia. She obtained her Master of Science degree from the Faculty of Management. Her area of expertise covers customer satisfaction, psychology of the entrepreneur, corporate entrepreneurship, and company growth. She has authored a monograph, a scientific paper in the journal Management, various scientific papers in conference proceedings, as well as technical papers.

Bostjan Antoncic is Full Professor of Entrepreneurship at the Faculty of Management, University of Primorska, Slovenia. His main research interests include corporate entrepreneurship, entrepreneurial networks, entrepreneurial personality, and international entrepreneurship. He has authored or co-authored fourteen books (eleven of them in the area of entrepreneurship) and various scientific research articles. His papers were published in academic journals such as the Journal of Business Venturing, Entrepreneurship and Regional Development, Industrial Management and Data Systems, Journal of Developmental Entrepreneurship, Journal of Enterprising Culture, Managing Global Transitions, Journal of Management Development, and Journal of Small Business and Enterprise Development. 


\section{REFERENCES}

1. Antoncic, B. (2002). Notranje podjetništvo: Prenova konstrukta in razvoj integrativnega modela. Intrapreneurship: Construct Refinementa and an Integrative Model Development, Društvo za akademske in aplikativne raziskave, Koper.

2. Antoncic, B. (2007). Intrapreneurship : A comparative structural equation modeling study. Industrial Management \& Data Systems 107 (3) : 309-325.

3. Antoncic, B. (2008). Notranje podjetništvo. V Podjetništvo, ur. Mitja Ruzzier et al., 93-101, Društvo za akademske in aplikativne raziskave, Koper.

4. Antoncic, B., Zorn, O. (2004). The mediating role of corporate entrepreneurship in the organizational support-performance relationship: An empirical examination. Managing global transitions 2 (1) : 5-14.

5. Antoncic, B., Hisrich, R. D. (2001). Intrapreneurship: Construct refinement and cross-cultural validation. Journal of Business Venturing 16 (5) : 495-527.

6. Antoncic, B., Hisrich, R. D. (2004). Corporate entrepreneurship contingencies and organizational wealth creation. Journal of Management Development 23 (6) : 518-550.

7. Auer, J., Antoncic, B. (2009). Zadovoljstvo zaposlenih, notranje podjetništvo in rast podjetja. Društvo za akademske in aplikativne raziskave, Koper.

8. Belbin, M. (1993). Team Roles at Work, Butterworh-Heinemann, Oxford.

9. $\quad$ Bush, R. P., Busy, A. J., and Hair Jr., J. F. (1990). Developing a Behavior-Based Scale to Assess Retail Salesperson Performance. Journal of Retailing 66 (Spring) : 119-136.

10. Driver, M. J., Coffey, R. E. and Bowen, D. E. (1988). Where Is HR Management, Personnel

11. Duboff, R. (1999). Employee loyalty: A key link to value growth. Strategy \& Leadership 27 (1) : 8-13.

12. Fiedler, F. (1993). The leadership situation and the black box in contingency theories, Academic Press, San Diego.

13. Hartline, M. D. and Ferrell, O. C. (1996). The Management of Customer-Contact Service Employees: An Empirical Investigation. Journal of Marketing 60 (October) : 52-70.

14. Heskett, J. L., Jones, T. O., Loveman, G. W., Sasser, Jr. W. E., Schlesinger, L. A. (1994). Putting the Service-Profit Chain to Work. Harvard Business Review (Mar-Apr) : 164-174.

15. Joy-Matthews, J., Megginson, D., Surtees, M. (2007). Human Resource development, Kogan Page, London.

16. Lobnikar, B. (2006). Management zaposlenih: študijsko gradivo: zapiski s predavanj, GEA College, Piran.

17. Majcen, M. (2004). Redni letni razgovor, GV Založba, Ljubljana.

18. Matzler, K., Renzl, B. (2006). The Relationship between interpersonal trust, employee satisfaction, and employee loyalty. Total Quality Management \& Business Excellence 17 (10) : 1261-1271.

19. Mayer, J. (1991). Ustvarjalno mišljenje in delo, Moderna organizacija, Kranj.

20. Merkac Skok, M. (2008). Zaposleni v organizaciji - Kadri v športu. V Šport: trženje športa, podjetništvo v športu, športna infrastruktura, šport v lokalni skupnosti, kadri v športu, zavarovanje v športu, ur. Dušan Gerlovič, 175-214, Sokolska zveza Slovenije, Ljubljana.

21. Mesner Andolsek, D. (1995). Organizacijska kultura. Ljubljana: Gospodarski vestnik.

22. Meyer, J. P. and Allen, N. J. (1997). Commitment in the workplace: theory, research and application. Thousand Oaks: Sage.

23. Michaels, R. E., Cron, W. L., Dubinsky, A. J. and Joachimsthaler, E. A. (1988). Influence of Formalization on the Organizational Commitment and Work Alienation of Salespeople and Industrial Buyers. Journal of Materials Research 25 (November) : 376-383.

24. Mihalic, R. (2008). Povečajmo zadovoljstvo in pripadnost zaposlenih. Škofje Loka: Mihalic in partner.

25. Miskell, J. R. and Miskell, V. (1994). Motivation at work. Burr Ridge: Irwin.

26. Mowday, R. T., Steers, R. M. and Porter, L. W. (1979). The Measurment of Organizational Commitment. Journal of Vocational Behavior 14 (April) : 224-247.

27. Mozina, S. (2002). Management kadrovskih virov, Fakulteta za družbene vede, Ljubljana.

28. Mozina, S. (2002). Odnosi med zaposlenimi v organizaciji, Industrijska demokracija, Kranj.

29. Tsui, A. S., Pearce, J. L., Porter, L. W., Tripoli, A. M. (1997): Alternative approaches to the employeeorganization relationship: Does investment in employees pay off? Academy of Management Journal 40 : 1089-1121. 
30. Varona, F. (2002). Conceptualization and Management of Communication Satisfaction and Organizational Commitment in Three Guatemalan Organizations. American Communication Journal 5 (3) : 114-136.

31. Welsby, P. (2003). Medosebno razumevanje - ključ do uspešnega dela z ljudmi. Human Resource Management 1 (1) : 56-57.

32. Zahra, S. A. (1991). Predictors and financial outcomes of corporate entrepreneurship: An exploratory study. Journal of Business Venturing 6 (4) : 259-285.

33. Zahra, S. A. (1993). Environment, corporate Entrepreneurship, and financial performance: A taxonomic approach. Journal of Business Venturing 8 (4) : 319-340. 
International Journal of Management \& Information Systems - First Quarter $2011 \quad$ Volume 15, Number 1 NOTES 